\title{
Causes of Back Pain. How to Treat?
}

\author{
Karski Tomasz ${ }^{1 *}$ and Karski Jacek ${ }^{2 * *}$ \\ ${ }^{1}$ Professor Lecturer in Vincent Pol University in Lublin \\ ${ }^{2}$ Assistant Professor in Pediatric Orthopedic and Rehabilitation Department of Medical University in Lublin \\ *Corresponding author: Karski Tomasz, Professor Lecturer in Vincent Pol University in Lublin, Poland
}

\begin{tabular}{ll} 
ARTICLE INFO & ABSTRACT \\
\hline
\end{tabular}

Received: 幽 April 03, 2019

Published: 慧 April 10, 2019

Citation: Karski T. Karski J. Causes of Back Pain, How to Treat?. Biomed J Sci \& Tech Res 16(5)-2019. BJSTR. MS.ID.002926.

Keywords: Back Pain; Causes; Physiotherapy
According to our observations there are following main causes of spinal pains syndromes, very frequent in many persons in many countries:

a) Lumbar hiperlordosis as result of hips flexion contracture.

b) Lumbar "C" or "S" scoliosis in Lublin classification (2 $2^{\text {nd }}$ etio-pathogenetical group [epg] - see literature) caused by permanent standing 'at ease' on the right leg.

c) Stiffness of the spine as clinical sign of scoliosis in $3^{\text {rd }}$ epg group in Lublin classification.

d) Spondylolisthesis or spodylolisis in sacral-lumbar or lumbar spine.

e) Other-rare causes.

According to authors- The proper treatment is physiotherapy. It is in opposition to other authors who mostly speak about "prolapsed nucleus" and they proposes surgery [1-7].

\section{Introduction}

In article we describe the causes of the back pain [8-19]. The same opinion was S Malawski et al. [20,21]. We describe also the possibility and effectiveness of physiotherapy of the back pain syndrome. We present details of ours physiotherapy methods.

\section{Hiperlordosis of lumbar Spine}

The deformity is connected with the hips flexion contracture, in result anterior tilt of pelvis and next "hiperlordosis of lower part of spine" what is the frequent cause of "back pain". The primary cause of "the back pain" is Minimal Brain Dysfunction (MBD) in newborn, babies and next in older children. When this disorder is not treated in adolescents period of life in adults causes the back pain. In some patients the hiperlordosis of lumbar spine can be the compensatory deformity of ante-pulsion position of shoulders. Such causes are mostly in women when in girls' period of life they had the habit to put shoulder forwards.

\section{Degenerative Lumbar or Lumbar-Thoracic Left Convex Curve}

In this group of patients the "back pain" in causes by so-called idiopathic scoliosis in second group in Lublin classification. There are "C" or "S" curves of the lumbar spine are connected with the special "model of hip movements" and next with "permanent standing 'at ease' on the rightleg". This asymmetry of hips movement is connected with the Syndrome of Contractures and Deformities $[21,22]$. The adduction of the right hips in straight position of joint is limited, because of this the hip joint is more stable and right leg is taken for permanent standing 'at ease' [23].

\section{Stiffness of the Spine}

In this group "the back pain" is connected with the stiffness of the spine. This deformity belong to scoliosis in 3rd epg group in Lublin classification. The spine deformity is connected with the special model of hip movements and next with "gait". In situation of maximal limited adduction of movement of right hip and limited movement of left hip (examination in straight position of joint)during gait the "absent movement of hip or hips" is transmitted to the pelvis and to the spine as bigger than normal rotation movement. In results of this rotation movement appears distortions in intervertebral joints and in next stiffness of the spine. The stiffness of the spine disturbed this activity and if is not present come to "pain's distensions symptoms". 
Spondylolisis or spondylo-listhesis: In this group the pain is because of dislocation of vertebra bodies mostly in the connection of L5 and S1, in some cause between L4 and L5, in other cases in two levels L4 - L5 - S1. The cause of spondylolisthesis can be congenital or acquisitioned. This second form is mostly after overloading of lumbar part of spine in special hard form of job in industry, in farmers work at cetera.

\section{Other - Rare Causes - Urgent and Acute "Prolapsed Nucleus"}

Patients in this group belong to the group with "hiperlordosis of lumbar spine" and to group with "degenerative left convex lumbar scoliosis". In older age, in special hard job situations, can appear "acute back pain syndrome" in lower part of spine. The annoying pain can be in lumbar or sacral - lumbar part of spine. The movement in this part of spine "in pain time" is totally limited. The urgent and acute "prolapsed nucleus" can appear in cervical part of spine. Other causes of "pain syndromes in cervical part of spine" is endezopathies.

\section{Material}

The whole material count 286 patients with the age 40-70. All patients suffered because of pain in lower part of spine. Precise diagnosis found the causes described in subchapters and mostly there were "hiperlordosis" and "degenerative scoliosis" of lumbar part of spine.

\section{Physiotherapy}

\section{Our Treatment in Points:}

a) Chair extension for the lumbar spine" for 20-30 minutes, five or more times every day. When heavy pain- extension should be longer time, even whole day.

b) Rest and sleeping in embryo position- mostly on the right side of the body.

c) Important in the therapy is to avoid the "standing 'at ease' on the right leg" in every day situations. We recommend to stand on the left leg or on both legs in abduction of 20-30 degree and in internal rotation of hips 15-20 degree.

d) Very beneficial is thermotherapy of lumbar spine, gentle hand massage, laser, local criotherapy, magnetic field, diadynamic.

e) Flexion exercises for the spine in the pain-free phase of the illness.

f) Stretching exercises to correct the position of the pelvis and to lengthen flexors of knees and of Achilles tendons, plus m. triceps surae.

\section{Conclusion}

a) The back pain causes are:

1. Lumbar hiperlordosis,

2. Scoliosis "C" or "S" in $2^{\text {nd }}$ group of spine deformity in Lublin classification,
3. Scoliosis in form of stiffness in $3^{\text {rd }}$ group of spine deformity in Lublin classification.

4. Spondylolisthesis-congenital or acquired. This group (points 1, 2, 3, 4) counts / embrace $95 \%$ of patients.

b) Prolapsed nucleus pulpous can be the cause of acute pain in patients from various groups described above. This group counts / embrace $5 \%$ of patients.

c) We recommend the prophylaxis and treatment of scoliosis by stretching exercises to receive full movement of hip, proper position of pelvis and full flexions and rotation movement of spine.

d) Important are: standing on the left leg, sitting relax-never straight up, rest in embryo position, stretching form of sport like karate, taekwondo, aikido, kung fu, yoga.

\section{References}

1. Abbott JH, Mercer SR (2002) The natural history of acute low back pain. New Zeeland Journal of Physiotherapy 30(3): 8-16.

2. Bazan M (2006) Bólowe zespoły kręgosłupowo-korzeniowe dolnego odcinka kręgosłupa (Spine and roots pain syndromes -in lower part of vertebra). „Skalpel” 2006/03 (maj-czerwiec) - pismo Wojskowej Izby Lekarskiej w Warszawa, Klinika Rehabilitacji CSK MON WIM w Warszawie.

3. Domżał TM (2006) Bóle krzyża (Back pain). Lekarz rodzinny 9: 930-941

4. Farfan HF (1973) Mechanical disorders of the low back. Lea \& Febiger, Philadelphia.

5. Saji M, Leong JCY (1995) Increased femoral neck-shaft angles in adolescent idiopathic scoliosis. Spine 20(3): 303-311.

6. Stokes IAF (1999) Studies in Technology and Informatics. Research into Spinal Deformities 59(2).

7. Tylman D (1995) Patomechanika bocznych skrzywień kręgosłupa, Wydawnictwo Severus, Warszawa, pp. 167.

8. Gardner A, Karski T (2000) Skoliozy tzw. idiopatyczne - przyczyny, rozwój i utrwalanie się wady. Profilaktyka i zasady nowej rehabilitacji. The etiology of the so-called idiopathic scoliosis. Progress and fixation of the spine disorders. The prophylaxis and principles of the new rehabilitation treatment, KGM, Lublin, p. 1-14

9. Karski T, Karski J, Madej J, Latalski M (2002) Persönliche Überlegungen zur Ätiologie der idiopathischen Skoliosen. Praktische Hinweise zur Entdeckung beginnender Skoliosen. Prinzipien der neuen Übungstherapie. Möglichkeiten der Prophylaxe. Orthop Praxis 38: 7583.

10. Karski T (2011) Biomechanical Etiology of The So-Called Idiopathic Scoliosis (1995-2007) Connection with "Syndrome of Contractures"Fundamental Information for Pediatricians in Program of Early Prophylactics. Journal of US-China Medical Science, USA 8(78).

11. Karski T, Kędzierski Z, Bartoszczyk A, Jabłoński M, Karski J (2012) History of orthopaedics in Lublin. Founding of the Orthopaedic Department of Medical University in 1954. Problems. The team. Didactics. Clinic and research aim in the years 1954-2012. Pohybove ustroji / Locomotor System, p. 3-4.

12. Karski T (2010) Factores biomechanicos en la etiologia de las escoliosis dinominadas idiopaticas. Nueva clasificacion. Nuevos test clinicos y nueavo tratamento conservador y profilaxis. Cuestiones de Fisioterapia, Mayo-Agosto 39 (2): 144-152.

13. Karski Tomasz, Jacek Karski (2015) Biomechanical etiology of the socalled Idiopathic Scoliosis (1995-2007). Causative role of gait and 
permanent standing 'at ease' on the right leg. New classification Principles of new therapy and causal prophylaxis. Canadian Open Medical Science \& Medicine Journal 1(1): 1-16

14. Karski Tomasz, Karski Jacek (2015) Syndrome of Contractures and Deformities" according to Prof. Hans Mau as Primary Cause of Hip, Neck, Shank and Spine Deformities in Babies, Youth and Adults. American Research Journal of Medicine and Surgery 1(2).

15. Karski Tomasz, Karski Jacek (2016) Bóle krzyża-problem neurologicznoortopedyczny. Objawy. Przyczyny. Leczenie. Back pain-neurologyorthopedic problems. Clinic, causes, therapy and prophylaxis. Postępy Neurologii Praktycznej.

16. Karski Tomasz (2017) Physiotherapy-Correct, or Incorrect, Based on 'Wrong Principles of Treatment'. Example for Spine, Hip, Knee, Shank and Feet. Crimson Publisher, p. 1- 4.

17. Karski Tomasz (2018) Biomechanical Aetiology of the So-called Adolescent Idiopathic Scoliosis (AIS). Lublin Classification (1995-2007) Causative Influences Connected with "Gait" and "Standing 'at ease' on the Right Leg", Scholarena. Journal of Orthopaedics and Bone Research

\section{ISSN: 2574-1241}

DOI: 10.26717/BJSTR.2019.16.002926

Karski Tomasz. Biomed J Sci \& Tech Res

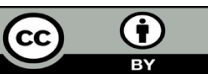

This work is licensed under Creative Commons Attribution 4.0 License

Submission Link: https://biomedres.us/submit-manuscript.php
Open Access, USA, p. 10

18. Krasuski M (2005) Algorytm postępowania diagnostyczno-leczniczego w zespołach bólowych kręgosłupa. Rehabilitacja Medyczna 9(3): 19-25.

19. Malawski S (1994) Własne zasady leczenia skolioz niskostopniowych w świetle współczesnych poglądów na etiologię i patogenezę powstawania skolioz. Chir Narz Ruchu i Ortop Pol 59(3): 1.

20. Mau H (1979) Zur Ätiopathogenese von Skoliose, Hüftdysplasie und Schiefhals im Säuglinsalter. Zeitschrift f Orthop 5: 601-605.

21. Gasik R, Styczyński T, Pyskło B (2007) Badanie priopriorecepcji w obrębie stawów kolanowych u chorych na dyskopatię lędźwiowego odcinka kręgosłupa. Reumatologia 45(4): 186-189.

22. Karski Tomasz, Jacek Karski (2017) Karate, Taekwondo, Aikido, Kung $\mathrm{Fu}$, Yoga and Other Far Easter Forms of Activities are not only Sport but also the best Method of Treatment of Locomotor's System Deformities. Journal of Yoga, Physical Therapy and RehabilitationIssue 4: 1-8.

23. Mau H (1982) Die Atiopatogenese der Skoliose, Bücherei des Orthopäden, Band 33, Enke Verlag Stuttgart, pp. 1-110.

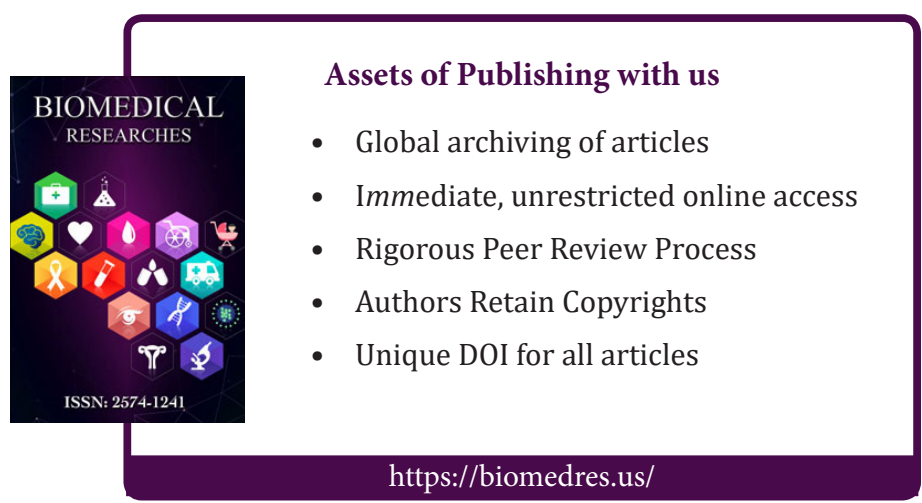

